\title{
KEDUKAAN PANDEMI COVID-19 MENENTANG PRINSIP KONSELING PASTORAL DI TENGAH TEMA REPOSISI PEKABARAN INJIL HKBP TAHUN 2020
}

\author{
Lamria Sinaga \\ Sekolah Tinggi Diakones HKBP \\ Sinagalamria2@gmail.com
}

\begin{abstract}
This article describes the debilitating grief situation of the entire community due to the Covid-19 pandemic. This grief causes heartbreak the requires guidance of pastoral counseling. This grief occurred because of the outbreak of the Covid-19 virus which obliged every community to do social/physical distancing, social resitrictions even lockdown. On the other hand, churches that are midst of the community have the responsibility to response and change that have occurred due to the Covid-19 pandemic. In 2020, HKBP set as the year repositioning the gospel, so HKBP needs to change its approach how to serve congregation/community. The method used to answer the problems posed in this paper is literature review by utilizing printed book sources, international websites and other articles related to the Covid-19 pandemic.
\end{abstract}

Key Word:grief, spirituality, Covid-19

\begin{abstract}
Abstrak
Artikel ini memaparkan situasi kedukaan yang dialami oleh seluruh masyarakat akibat pandemic covid-19. kedukaan tersebut menimbulkan kesedihan hati yang membutuhkan pendampingan/penanganan konseling pastoral. Kedukaan ini terjadi karena mewabahnya virus covid19 yang mengharuskan setiap masyarakat melaksanakan social/physical distancing, pembatasan sosial berskala besar hingga lockdown. Di sisi lain gereja yang berada di tengah-tengah masyarakat memiliki tanggungjawab untuk merespon perubahan yang terjadi akibat pandemic covid-19 sebagaimana HKBP menetapkan tahun 2020 sebagai tahun reposisi pekabaran injil maka HKBP perlu mengevaluasi dan merubah pendekatan dalam melayani masyarakat. Metode yang digunakan untuk menjawab permasalahan yang diajukan dalam tulisan ini adalah kajian literatur dengan memanfaatkan sumber buku cetak, website internasional dan artikel lain yang berhubungan dengan pandemic covid-19.
\end{abstract}

Kata Kunci: Kedukaan, Spiritualitas, Covid-19

\section{PENDAHULUAN}

Awal tahun 2020, dunia dikejutkan dengan ditemukannya jenis penyakit yang baru yang disebut dengan Virus Corona. Penyakit Coronavirus (COVID-19) adalah jenis penyakit menular disebabkan oleh Coronavirus. Berdasarkan catatan dari WHO (World Health Organization - Organisasi Kesehatan Dunia) pada 31 Desember 2019 informasi tentang penyakit COVID-19 mulai diberitakan sebagai kasus pneumonia etiologi yang tidak diketahui penyebabnya dan terdeteksi pertama sekali di Kota Wuhan, Provinsi Hubei Cina. Otoritas nasional negara Cina melaporkan bahwa semua pasien yang terinfeksi diisolasi dengan gejala klinis utamanya adalah demam, mengalami kesulitan bernafas, dan radiografi dada menunjukkan lesi invasif pada kedua paru-paru. Hingga akhir bulan Januari 2020, tercatat ribuan orang di Provinsi Hubei Cina telah meninggal karena terinfeksi Penyakit Coronavirus. 
Keadaan tersebut mendorong WHO dan beberapa organisasi kesehatan lainnya mengadakan penelitian mendalam tentang penyebaran Penyakit Coronavirus. Pada tanggal 11 Pebruari 2020, WHO kemudian resmi mengumumkan tentang keberadaan Penyakit Coronavirus dengan istilah CORONA VIRUS DISEASE-19 (COVID-19) dan pada tanggal 11 Maret 2020 WHO secara resmi mengumumkan COVID-19 sebagai pandemic darurat kesehatan global. Pandemic merupakan suatu penyakit menular yang tersebar dengan mudah dari manusia ke manusia di berbagai tempat di seluruh dunia.

Wabah COVID-19 telah membuat dunia berubah dan seolah-olah berhenti dari rutinitasnya. Hal ini dilihat dari dampak yang lahir dari Wabah COVID-19 yang menyentuh hampir setiap sendi-sendi kehidupan manusia. Kehidupan perekonomian manusia terancam dikarenakan risiko yang berkembang dari resesi global karena hilangnya pekerjaan. Disisilain, kehidupan sosial manusia juga mengalami perubahan drastis. Mengacu kepada pengertiannya, interaksi sosial merupakan kunci dari semua kehidupan sosial: tanpa ada interaksi sosial tak mungkin ada kehidupan bersama ${ }^{1}$. Interaksi sosial bukan hanya sekedar bertemu namun berusaha menghasilkan kualitas hidup dalam suatu kelompok sosial. Kualitas hidup akan terjadi apabila individu atau kelompok manusia bertemu langsung, bekerjasama, saling berbicara, menukar pengalaman/pikiran/pandangan, mengadakan persaingan, dan bahkan mengadakan pertikaian. Diperhadapkan kedalam situasi pandemic COVID-19, organisasi kesehatan telah mencetuskan bahwa interaksi sosial merupakan pemicu utama penyebaran COVID-19 sehingga social/physical distancing, pembatasan social berskala besar (PSBB), hingga lockdown dijadikan sebagai disiplin utama yang wajib untuk dipatuhi di seluruh daerah/negara yang memberlakukannya. Dengan penerapan disiplin tersebut maka dapatlah dikatakan bahwa pandemic COVID-19 juga mengakibatkan degradasi interaksi sosial manusia.

Sebagai pandemic global, COVID-19 adalah krisis kesehatan yang juga berdampak keras pada bidang pendidikan, misalnya banyak negara memutuskan untuk menutup sekolah, perguruan tinggi dan universitas. Penutupan tersebut tidak hanya mengganggu pengajaran di seluruh dunia tetapi juga bertepatan dengan periode pelaksanaan penilaian utama bagi pelajar yang akhirnya banyak ujian telah ditunda hingga dibatalkan. Tidak dapat dipungkiri situasi tersebut tentu membawa pengaruh didalam pengukuran dan pembuktian kualitas pelajar selama periode pandemic ini berlangsung. Belajar dan bekerja dari rumah merupakan metode baru bagi kebanyakan orang. Metode pembelajaran online [yang hingga sampai sekarang belum dilakukan pengujian keefektivitasannya pada skala besar] merupakan satu-satunya pilihan untuk meminimalisir dampak pada sektor pendidikan.

\footnotetext{
${ }^{1}$ Kamanto Sunarto, Pengantar Sosiologi Dan Perubahan Sosial (Jakarta: Bina Cipta, 2004).
} 


\section{METODE PENELITIAN}

Tulisan ini menggunakan metode penelitian literatur atau kepustakaan. Permasalahan dalam tulisan ini dideskripsikan dan dianalisis serta dijawab berdasarkan bahan pustaka yang mendukung topik tulisan berupa buku, jurnal dan website internasional.

\section{HASIL DAN PEMBAHASAN}

\section{Kedukaan pandemic akibat COVID-19}

Pandemi COVID-19 yang menyapu seluruh dunia, menyebabkan kekhawatiran, ketakutan, dan stress. Semua hal tersebut merupakan reaksi alami dan normal terhadap situasi yang berubah dengan cepat dan menimbulkan ketidakpastian. Dalam diskusi mata kuliah Pastoral Klinis dengan mahasiswa STD HKBP T.A 2019/2020 yang dilakukan secara online [juga akibat COVID-19 dalam bidang pendidikan] menyimpulkan bahwa COVID-19 membawa kedukaan yang bersifat pandemic. Kesimpulan tersebut mengacu kepada pengertian kata kedukaan yang berarti suasana hati dan atau sedih hati yang diakibatkan oleh suatu peristiwa kehilangan. Definisi berdasarkan Baker Encyclopaedia of Psychology menyatakan bahwa kedukaan merupakan proses kognitif dan emosi dalam menghadapi kehilangan sesuatu yang berharga.

Keadaan darurat COVID-19 di seluruh dunia dengan pasti membawa kedukaan bagi manusia dalam semua usia. Sebagian besar orang mengalami trauma dan atau mengalami kembalinya perasaan/pengalaman trauma lama. Salah satu pemicu trauma dan atau kembalinya trauma lama dikarenakan kehadiran COVID-19 yang sangat tidak terduga, tiba-tiba dan mendadak. Kedukaan pandemic COVID-19 terlihat kedalam 2 bentuk, yaitu kedukaan berwujud (tangible of grief) dan kedukaan tidak berwujud (intangible of grief). Kedukaan berwujud merupakan kedukaan karena kehilangan sesuatu yang memiliki wujud/dapat diraba, disentuh, seperti kematian orang yang dikasihi. Kedukaan tidak berwujud kehilangan susuatu yang nyata namun tidak dapat disentuh/diraba, seperti kehilangan rasa aman, kehilangan kemampuan kesehatan, kehilangan control, kehilangan pekerjaan, kehilangan kepercayaan, kehilangan kesempatan.

Pada dasarnya, kedukaan bukanlah suatu penyakit namun kedukaan mampu menimbulkan penyakit atau sesuatu yang tidak normal. Hal ini dapat dipahami jika kejadian sedih hati yang diakibatkan oleh suatu peristiwa kehilangan berkepanjangan hingga menjadi akut dan tanpa ada pendampingan/penanganan, maka kedukaan akut akan mengakibatkan penyakit hingga kematian. Hal ini juga dijelaskan oleh Sherry Cormier, PhD dalam artikelnya "Grief and COVID-19: Mourning our bygone lives". . Dr Hans Henri P. Kluge, Direktur Regional WHO untuk Eropa dalam artikel "Mental

\footnotetext{
${ }^{2}$ Cormier Sherry, "Grief and Covid-19: Mourning our bygone lives," www.apa.org, n.d.
} 
health and psychological resilience during the COVID-19 pandemic"'3; Kirsten Weir dalam artikel "Grief and COVID-19: saying goodbye in the age of physical distancing"...

Jika selama ini yang dipahami dan dipraktekkan bahwa salah satu cara yang paling teruji untuk menolong dan mendampingi orang yang mengalami kesedihan/kedukaan adalah dengan membangun kualitas hubungan/interaksi sosial yang sehat. Dalam konteks pandemic COVID-19 sekarang ini, tentu cara yang telah teruji tersebut tidak dapat dilakukan. Realita saat ini, pada umumnya kesedihan dan kedukaan dilami dan harus dikelola dengan sendiri, terisolasi secara sosial, tidak mendapatkan kebutuhan akan kenyamanan fisik/mental/sosial/spiritual dari teman/kolega dan bahkan dari keluarga. Kedukaan akibat pandemic COVID-19 mengubah cara banyak orang untuk mati. Bahkan ritual untuk mengucapkan selamat tinggal kepada orang yang dicintai karena kematian tidak dapat dilakukan lagi.

\section{Kedukaan pandemic COVID-19 dan prinsip layanan konseling pastoral}

Berangkat dari pemahaman diatas bahwa jika kesedihan/kedukaan akut tidak diberikan pendampingan/penanganan akan menimbulkan berbagai penyakit mental dan fisik yang dapat berujung kepada kematian. Kedukaan, kesepian, marah [tidak menutup kemungkinan marah kepada Tuhan juga] mempengaruhi kondisi kesehatan fisik atau sistem organ manusia. Ketika tekanan dan stress mengancam hidup seseorang, penyakit pun akan datang, fungsi organ tubuh akan terganggu baik secara fungsi maupun secara strukturnya ${ }^{5}$. Dalam tulisan ini akan dijelaskan tentang pendampingan pastoral diperhadapkan kepada situasi pandemic COVID-19.Aart Van Beek menjelaskan istilah pendampingan pastoral sebagai gabungan dua kata yang mempunyai makna pelayanan, yaitu pendampingan dan pastoral. Kata pendampingan berasal dari kata kerja "mendampingi" yaitu suatu kegiatan menolong orang lain yang perlu didampingi. Pendamping dilakukan dengan mengandalkan hubungan interaksi atau relasi timbal-balik. Dengan demikian, istilah pendampingan memiliki arti kata kerja saling menumbuhkan dan mengutuhkan diantara pendamping dan yang didampingi ${ }^{6}$. Pendampingan Pastoral disebut juga sebagai penyembuhan jiwa sebagaimana dituliskan oleh Thomas C. Oden dalam bukunya 'Pastoral Theology' bahwa pendampingan pastoral menggunakan kata 'soul care' [penyembuhan/perawatan jiwa] sebagai terminasi kata untuk pendampingan pastoral.

Dalam konteks pendampingan orang berduka berarti pendampingan yang dikhususkan bagi orang yang berduka. Orang berduka dipandang sebagai tubuh Kristus yang harus diberikan perhatian secara khusus dalam bentuk pelayanan secara medis maupun non-medis. Pendampingan secara non-

\footnotetext{
${ }^{3}$ Kluge Hans Henri, "Physical and Mental Health Key to Resilience during COVID-19 Pandemic," March 26, 2020, accessed March 27, 2020, https://www.euro.who.int/en/about-us/regionaldirector/news/news/2020/03/mental-health-and-psychological-resilience-during-the-covid-19-pandemic.

${ }^{4}$ Weir Kristen, "Grief and COVID-19: saying goodbye in the age of physical distancing," April 6, 2020, accessed April 6, 2020, www.apa.org.

${ }^{5}$ Simon Doniger, Healing: Human and Divine (New York: Assocation Press, 1957).

${ }^{6}$ Aart Van Beek, Pendampingan Pastoral (Jakarta: Gunung Mulia, 2012). 9
} 
medis yaitu pendampingan pastoral yang memandang orang berduka sebagai manusia utuh yang membutuhkan sentuhan dan pendampingan dengan penuh kasih. Pendampingan pastoral merupakan suatu fungsi yang bersifat memperbaiki, yang dibutuhkan ketika orang mengalami krisis yang merintangi pertumbuhannya ${ }^{7}$. Berdasarkan penjelasan diatas dapat disimpulkan bahwa pendampingan pastoral pada dasarnya merupakan pelayanan pendampingan yang bertujuan untuk menolong orang yang membutuhkan dengan memanfaatkan interaksi atau relasi diantara penolong, orang yang ditolong dan Tuhan. Dengan demikian dalam pelayanan pendampingan pastoral hal yang menjadi poin utama konseling pastoral yaitu menolong orang yang membutuhkan melalui kehadiran secara penuh sehingga kualitas hubungan terbina diantara pihak yang terlibat didalamnya (konselor pastoral, konseli dan Tuhan $)^{8}$.

Pokok pikiran dan sorotan penting untuk dipertanyakan adalah, dalam konteks kedukaan pandemic COVID-19 siapakah yang berperan sebagai penolong (konselor pastoral), orang yang ditolong (konseli)? Sebab dalam situasi ini, kedukaan bersifat pandemic: menyerang semua orang dalam segala usia, pekerjaan dan jenis kelamin. Dengan artian kedukaan pandemic COVID-19 juga membawa pengaruh bagi konselor pastoral dan konseli. Bahkan dalam proses kedukaan pandemic COVID-19 ini, bagi sebagian besar orang, Tuhan sepertinya sedang absen, tidak hadir, bersembunyi dan seolah-olah membiarkan manusia berduka sendiri.

\section{Siapakah pelaku pendampingan pastoral?}

Dalam bukunya 'Introduction to Pastoral Counseling' Loren Townsend menjelaskan bahwa seorang pelayan pendampingan pastoral adalah mereka yang mengorganisir pekerjaan dan pikirannya berdasarkan identitasnya; mengintegrasikan kemampuan pengetahuan dan teologi, spiritualitas dan psikologi. Dengan demikian yang menjadikan ciri khusus layanan konseling pastoral/pendampingan pastoral terletak pada siapa yang memberikan layanan tersebut yaitu seorang pelayan dengan keistimewaan identitas diri sebagai seorang pelayan.

Peran seorang pendamping terletak pada kepeduliaannya yang memberikan diri untuk hadir secara penuh, hadir bersama dan hadir untuk mendukung orang yang membutuhkan. Yesus Kristuslah lah yang berperan, sebagai pemeran utama dan bertanggungjawab untuk kesembuhan dan keutuhan, orang percaya berperan sebagai mediator hubungan manusia dengan Tuhannya. Pemahaman ini lah yang menghantarkan kepada pernyataan bahwa setiap orang Kristen yang mengimani Yesus Kristus terpanggil untuk menjadi bagian dari pekerjaan-Nya sebagai wakil dan perpanjangan tangan Tuhan dalam karyaNya di dunia. Berdasarkan penjelasan tersebut maka pendampingan pastoral merupakan panggilan bagi semua orang Kristen, karena melalui pendampingan pastoral orang Kristen

\footnotetext{
${ }^{7}$ Howard Clinebal, Tipe-Tipe Dasar Pendampingan Dan Konseling Pastoral (Yogyakarta: Kanasius, 2002). ${ }^{8}$ Lamria Sinaga, "Manfaat Konseling Bagi Pasien Rawat Inap Di RSU HKBP Balige," Jurnal Diakonia STD HKBP 7 (1) (2019).
} 
menunjukan perwujudan kasih dan kepedulian Kristus lewat kehadirannya di tengah-tengah orang yang membutuhkan secara khusus orang yang berduka.

Orang Kristen terpanggil untuk turut hadir ditengah-tengah orang yang membutuhkan, dan mengalami krisis (secara khusus dalam situasi kedukaan pandemic COVID-19) untuk memberikan pendampingan pastoral. Pendampingan pastoral merupakan sebutan untuk konseling Krsiten. Adapun konseling Kristen mempunyai tiga keunikan yang mana melalui keunikan tersebut, proses kesembuhan "dapat" terjadi. Keunikan yang pertama adalah, pendampingan pastoral terlaksana atas dasar pemahaman bahwa orang Kristen percaya kepada Allah sang Pencipta. Dengan kepercayaan tersebut setiap orang Kristen mengimani bahwa Allah yang adalah Pencipta juga berperan sebagai pemelihara, mendengarkan doa dan menolong setiap ciptaan-Nya. Keunikan yang kedua adalah pendampingan pastoral mempunyai misi khusus yaitu merekonsiliasi hubungan yang rusak diantara manusia dan Tuhan. Dengan demikian kesadaran akan hadirnya Tuhan dalam setiap proses percakapan dan pendampingan merupakan letak keistimewaan konseling Kristen. Keunikan yang ketiga adalah pendampingan pastoral mempunyai cara pendekatan dengan penekanan tidak hanya pada kemampuan keterampilan dan pengetahuan seorang pendamping/konselor/pelayan tetapi juga penggunaan sumbersumber keagamaan Kristen, seperti berdoa, nyanyian, meditasi, pembacaan Firman dan perjamuan kudus.

\section{Pelayanan konseling pastoral ditengah pandemic COVID-19}

Berdasarkan pemaparan diatas dijelaskan bahwa pihak yang memberikan layanan pendampingan pastoral pertama-tama dan yang terutama adalah pelayan gereja dengan keistimewaan identitas diri sebagai seorang pelayan. Kemudian panggilan untuk melakukan pendampingan pastoral juga merupakan bagian dari praktek hidup orang Kristen (orang percaya) melalui kepeduliaannya yang memberikan diri untuk hadir secara penuh, hadir bersama dan hadir untuk mendampingi orang yang membutuhkan. Dengan demikian panggilan untuk mendampingi dan meneguhkan mereka yang berduka bukan dibatasi kepada para pelayan gereja saja, tetapi merupakan panggilan bagi semua orang yang percaya.Kenyataan yang telah terjadi adalah social/physicaldistancing dan PSBB (pembatasan sosial berskala besar) mengharuskan orang untuk tetap tinggal di rumah saja dan tidak melakukan segala bentuk perjalanan/pertemuan/perkunjungan. Bahkan pemerintah telah mengaturkan tindak disiplin bagi yang melanggar peraturan dan kebijakan tersebut. Keadaan tersebut membatasi ruang gerak/pergaulan dan menumbuhkan keengganan untuk bertemu dengan orang lain. Bahkan keadaan tersebut turut mempengaruhi pelayanan gereja dan jemaat gereja untuk melakukan pendamping pastoral. Ironisnya, saat ini bahkan ada pelayan yang menolak untuk memberikan sakramen kepada jemaat yang sakit di rumah sakit yang meminta untuk pelayanan Perjamuan Kudus. Hal ini didasarkan kepada ketakutan pelayan untuk berkunjung ke rumah sakit dan kontak dengan orang-orang yang berada disana, meskipun orang sakit tersebut bukanlah pasien ODP, PDP atau positif COVID-19. Jika 
dilihat dari sisi lain, bahwa kedukaan yang dialami adalah kedukaan pandemic yang menyentuh seluruh aspek kehidupan manusia pada setiap golongan dan usia tanpa terkecuali pelayan gereja dan jemaat (orang percaya) juga sedang mengalami kedukaan. Pandemic COVID-19 menuntut banyak perubahan hampir dalam setiap aspek kehidupan manusia. Perubahan tersebut bukanlah sesuatu hal yang dapat ditawar kapan terjadi sehingga dapat diulur waktu terjadinya atau ditunda. Satu hal yang jelas: dunia harus memberi respon terhadap perubahan tersebut secara terintegrasi dan komprehensif dengan melibatkan seluruh pemangku kepentingan, mulai dari pemerintah, sektor publik dan swasta, para akademisi, masyarakat dan gereja.

Sesungguhnya, ditengah perkembangan global dan teknologi saat ini dimana peradaban dunia sedang berada pada fase Revolusi Indsutri 4.0; dunia telah dipersiapkan untuk menghadapi perubahan akibat dampak pandemic COVID-19. Hadirnya revolusi Indsutri 4.0 dipandang membawa dampak positif dan dampak negative. Dampak positif seperti: pemanfaatan teknologi telah memungkinkan penjualan produk dan jasa secara cepat dan efisien; teknologi begitu menyentuh pola kehidupan manusia secara personal dari berbagai sudut: teknologi berfungsi sebagai sekretaris pribadi, pengatur kesehatan, diet dan olah raga, memesan taksi/gojek, pesan makanan, beli tiket, mengatur perjalanan, main game, membaca buku dan sebagainya; teknologi memperluas interaksi sosial secara jaringan diantara manusia. Semua ini dapat dilakukan hanya melalui satu perangkat teknologi yang tersambung dengan jaringan internet. Disisilain, Revolusi Indsutri 4.0 yang identic dengan sistem otomatisasi juga dapat mengakibatkan pemiskinan dan pengkotak-kotakan masyarakat, memperdalam jurang kesenjangan sosial, menciptakan risiko keamanan yang baru, serta dapat merusak hubungan antar manusia. Perkembangan teknologi yang melahirkan era Revolusi Industri 4.0, telah menimbulkan disrupsi dalam berbagai bidang kehidupan manusia. Akibat yang ditimbulkan dari disrupsi ini membuat tatanan dunia berubah drastis 9 .

Jika diperhadapkan kedalam situasi pandemic COVID-19 dan era Revolusi Industri 4.0; situasi tersebut menuntut dunia harus memberi respon terhadap perubahan yang terjadi sebagai akibat dari munculnya dua fenomena tersebut. Dua situasi tersebut melahirkan dampak yang hampir sama, seperti cara/kualitas hidup, cara bekerja, cara belajar, sistem kepemilikan dan berhubungan satu sama lain. Perlu diingat bahwa pandemic COVID-19 dan era Revolusi Industri 4.0 tidak hanya membawa dampak negative tetapi juga berpotensi memberikan dan meningkatkan kualitas hidup dan kesejahteraan manusia. Oleh karena itu, respon dunia (manusia) terhadap perubahan akibat pandemic COVID-19 dan era Revolusi Industri 4.0 menjadi kunci keberlangsungan hidup manusia.

\section{Metode pelaksanaan konseling pastoral ditengah situasi pandemi COVID-19}

\footnotetext{
${ }^{9}$ Banu \& Umi Trisyanti prasetyo, "Revolusi Industri 4.0 Dan Tantangan Perubahan Sosial" (5) (2018), http://iptek.its.ac.id/index.php/jps/article/view/4417.
} 
Pada penjelasan tentang pendampingan pastoral diatas bahwa semua orang Kristen terpanggil untuk melakukan pendampingan pastoral. Pendampingan pastoral dilakukan dengan hadir secara penuh, hadir bersama dan hadir untuk mendampingi orang yang membutuhkan. Dalam Kamus Besar Bahasa Indonesia, kata 'hadir' mengandung makna "ada; (ada) datang" kehadiran merupakan kata benda mengandung arti "perihal hadir; adanya (seseorang/sekumpulan orang) pada suatu tempat". Berangkat dari makna tersebut bahwa tidak ada pembatasan makna hadir dalam bentuk pertemuan fisik atau harus ada pertemuan secara bersentuhan/bersinggungan secara fisik atau tatap muka langsung. Dengan demikian, hadir melalui keberadaan visual dan suara melalui pemanfaatan kamampuan teknologi dapat digunakan untuk menghadirkan (membuat supaya hadir/datang pada suatu tempat) orang.

Pemahaman kata 'hadir' diatas, jika dikaitkan dengan perkembangan era teknologi di Revolusi Industri 4.0; maka pendampingan pastoral dapat dilakukan dengan memanfaatkan peluang fasilitas dan aplikasi teknologi yang tersedia. Hal ini terlihat dari praktek yang telah dilakukan oleh gereja-gereja dan organisasi keagamaan selama wabah pandemic COVID-19 ini berlangsung. Gereja memanfaatkan jaringan internet, live streaming, aplikasi teknologi (zoom cloud meeting, Google hangout meeting), pemanfaatan telepon genggam (handphone), youtube, electronic news and email untuk memberikan pendampingan pastoral kepada segenap jemaat dan warga. Jika gerakan ini telah dimulai oleh gereja dan gerakan ini juga sebaiknya mampu memotivasi warga gereja dan segenap orang percaya untuk turut melakukan pelayanan pendampingan pastoral, secara khusus bagi mereka yang belum terjangkau oleh perkembangan teknologi. Perlu dicatat bahwa interaksi sosial tidak dibatasi dalam bertemu secara fisik saja, selama komunikasi terjalin maka interaksi kelompok sosial tetap akan terjaga ${ }^{10}$. Dengan demikian berlangsungnya dan terjalinnya komunikasi yang baik [dimana dalam komunikasi tersebut termuat layanan pendampingan pastoral], maka interaksi sosial tetap terjaga dan hubungan diantara jemaat dan gereja/pelayan gereja tetap hidup.

Gereja HKBP menetapkan tahun 2020 sebagai Tahun Reposisi Pekabaran Injil. Penetapan Tahun Reposisi Pekabaran Injil HKBP telah direncanakan sejak tahun-tahun sebelumnya yang penetapannya (launching) dilakukan pada tanggal 3 Januari 2020 pada saat acara open house Kantor Pusat HKBP di Peraja Tarutung. Pemilihan tahun Reposisi Pekabaran Injil HKBP menjadi tantangan tersendiri bagi gereja HKBP ditengah pandemic COVID-19 ini: "Bagaimana melakukan pekabaran Injil ditengah kedukaan pandemic COVID-19 ini?” Dengan demikian, diperlukan upaya dan cara agar gereja (pelayan gereja) dapat mendengar dan memahami jemaat dan jemaat dapat menerima pemberitaan Injil. Gereja perlu mengetahui dan menemukan bagaimana strategi dan metode pemberitaan Firman Tuhan yang relevan dan aktual, sesuai dengan konteks kebutuhan pada saat ini. Dalam bukunya "Reposisi Pekabaran Injil", Pdt. Dr. Darwin Lumbantobing menuliskan bahwa

\footnotetext{
${ }^{10}$ Sunarto, Pengantar Sosiologi Dan Perubahan Sosial.
} 
pengutusan pada nabi, rasul dan utusan Allah dengan berulang kali dan dalam berbagai cara menunjukkan sikap dan tindakan Allah yang selalu terbuka mengubah pendekatan yang dilakukanNya kepada manusia. Allah telah berkali-kali dan dengan berbagai metode pendekatan melakukan rencana penyelamatan kepada manusia ${ }^{11}$. Dengan demikian, ada pergantian dan perubahan cara pendekatan kepada manusia yang tentunya pendekatan tersebut harus sesuai dengan kehendak Allah dan untuk kesejahteraan manusia. Mereposisi metode pelaksanaan tri tugas panggilan gereja (koinonia, marturia dan diakonia) menjadi suatu keharusan bagi gereja masa kini. Gereja tidak boleh lagi hanya menekuni dan menjalankan pola lama yang berfokus pada kebiasaan dan tradisi yang tidak pernah dievaluasi ${ }^{12}$. Bagimana cara gereja untuk pergi melakukan tugas pengutusan tersebut di tengah situasi pandemic COVID-19 ini? Gereja perlu melakukan pergantian dan perubahan cara pendekatan dalam melakukan misinya tentunya dengan memperhatikan tuntutan zaman dimana saat ini sedang dunia sedang berada pada era Revolusi Industri 4.0.

Kedukaan pandemic COVID-19 dan perkembangan teknologi pada Revolusi Industri 4.0. ; dua periode yang hadir hampir bersamaan tetapi dilatarbelakangi oleh hal yang berbeda. Gereja HKBP diharapkan mampu merespon keadaan tersebut dengan kesungguhan melaksanakan makna yang terkandung dalam "Reposisi Pekabaran Injil HKBP". Dengan demikian, dalam situasi kedukaan pandemic COVID-19, gereja harus tetap melakukan misinya, yaitu misi Kristus diutus dan pergi ke tengah-tengah dunia untuk memberitakan Kerajaan Allah.

Pdt. Dr. Darwin Lumbantobing menuliskan Mazmur 137:1-4 sebagai tema dalam tahun Reposisi Pekabaran Injil HKBP tahun 2020; "Bagaimanakah kita menyanyikan nyanyian Tuhan di negeri asing?". Kemudian tema tersebut dijelaskan dengan pemaparan refleksi “jika menyanyikan lagu pujian untuk Tuhan di negeri sendiri tentu tidak ada masalah; tetapi bagaimana bila kita bernyanyi di negeri asing, di negeri orang yang menjajah dan menyiksa kita?" Pernyataan tersebut jika dikaitkan dalam konteks sekarang ini, ditengah kedukaan pandemic akibat COVID-19 maka pertanyaan refleksinya adalah "Bagaimanakah gereja menyanyikan nyanyian Tuhan ditengah wabah pandemic COVID-19?"; jika menyanyikan lagu pujian untuk Tuhan di negeri yang aman tentram tentu tidak ada masalah; tetapi bagaimana cara gereja bernyanyi ditengah kedukaan pandemic yang melanda dunia, dimana didalamnya gereja turut merasakan kedukaan tersebut?" Satu hal yang pasti bahwa gereja yang hidup adalah gereja yang terus bernyanyi dan berpengharapan, yang mampu melihat dan mengimani akan adanya masa depan didalam Tuhan. Jika Tuhan yang telah memilih dan menetapkan gereja dan setiap orang yang percaya untuk pergi dan menghasilkan buah (Yoh. 15:16), Tuhan jugalah yang akan memperlengkapi umat-Nya bagi pekerjaan pelayanan dan pembangunan tubuh Kristus (Efesus 4:11-12) ditengah dunia yang sedang berduka.

\footnotetext{
${ }^{11}$ Darwin Lumbantobing, Reposisi Pekabaran Injil (Jakarta: Gunung Mulia, 2019). 63

${ }^{12}$ Ibid. 66-67
} 


\section{KESIMPULAN}

Kedukaan yang disebabkan oleh pandemic covid-19 terdapat dalam dua bentuk yaitu kedukaan yang dirasakan dan kedukaan yang tidak dirasakan. Pada hakikatnya kedukaan bukanlah sebuah penyakit tetapi disebabkan oleh peristiwa yang tidak biasanya terjadi dan menimbulkan kesedihan bagi banyak orang. Dalam hal ini koseling pastoral berperan untuk menopang, meneguhkan mereka yang mengalami kedukaan akibat pandemic covid-19.

\section{DAFTAR PUSTAKA}

Beek, Aart Van. Pendampingan Pastoral. Jakarta: Gunung Mulia, 2012.

Clinebal, Howard. Tipe-Tipe Dasar Pendampingan Dan Konseling Pastoral. Yogyakarta: Kanasius, 2002.

Doniger, Simon. Healing: Human and Divine. New York: Assocation Press, 1957.

Hans Henri, Kluge. "Physical and Mental Health Key to Resilience during COVID-19 Pandemic," March 26, 2020. Accessed March 27, 2020. https://www.euro.who.int/en/about-us/regional-director/news/news/2020/03/mentalhealth-and-psychological-resilience-during-the-covid-19-pandemic.

Kristen, Weir. "Grief and COVID-19: saying goodbye in the age of physical distancing," April 6, 2020. Accessed April 6, 2020. www.apa.org.

Lumbantobing, Darwin. Reposisi Pekabaran Injil. Jakarta: Gunung Mulia, 2019.

prasetyo, Banu \& Umi Trisyanti. "Revolusi Industri 4.0 Dan Tantangan Perubahan Sosial” (5) (2018). http://iptek.its.ac.id/index.php/jps/article/view/4417.

Sherry, Cormier. “Grief and Covid-19: Mourning our bygone lives.” Www.apa.org, n.d.

Sinaga, Lamria. "Manfaat Konseling Bagi Pasien Rawat Inap Di RSU HKBP Balige.” Jurnal Diakonia STD HKBP 7 (1) (2019).

Sunarto, Kamanto. Pengantar Sosiologi Dan Perubahan Sosial. Jakarta: Bina Cipta, 2004. 